\title{
Prevalence of human papillomavirus infection among women from quilombo communities in northeastern Brazil
}

\author{
Maria do Desterro Soares Brandão Nascimento ${ }^{1,4,7^{*}}$, Flávia Castello Branco Vidal ${ }^{2,4}$, \\ Marcos Antonio Custódio Neto da Silva ${ }^{3}$, José Eduardo Batista', Maria do Carmo Lacerda Barbosa ${ }^{5}$, \\ Walbert Edson Muniz Filho', Geusa Felipa de Barros Bezerra', Graça Maria de Castro Viana', \\ Rebeca Costa Castelo Branco ${ }^{4}$ and Luciane Maria Oliveira Brito ${ }^{6,4}$
}

\begin{abstract}
Background: Human papillomavirus (HPV) is a member of the Papillomaviridae family. The prevalence of HPV genotypes may vary according to the region and the population studied. Quilombo communities are ethnic and racial groups with difficult access to health services compared to the general population in Brazil. The aim of this study was to identify specific HPV types correlating with sociodemographic/behavioral characteristics and cervical smear cytological abnormalities in Quilombola women.

Methods: This cross-sectional study included 395 Quilombola women users of the Unified Health System of the Municipalities of Maranhão for the screening of cervical cancer. The samples were analyzed for the presence of cytological abnormalities by conventional methods and tested for 37 HPV genotypes using polymerase chain reaction with primers PGMY09/11 followed by reverse line blot hybridization performed with the Linear Array HPV Genotyping Test kit by Roche Molecular System ${ }^{\circledast}$. The association between HPV types and cytological diagnosis was investigated according to the different age groups.

Results: HPV infection was detected in $12.6 \%(50 / 395)$ of the women. Infections by high-risk HPV types were more frequent. Genotypes 68 (26.0\%); 58 and 52 (20.0\%); 31 (10.0\%) and 62 (8.0\%) were the most prevalent. The highest prevalence (42.0\%) of HPV infection occurred in women diagnosed with high-grade squamous intraepithelial lesion. There was a statistically significant association between HPV infection and the detection of cytological abnormalities in all age groups except in women over 60 years. There was a statistically significant association between the municipality of origin and the number of partners with HPV infection.
\end{abstract}

Conclusions: It is important to incorporate new cervical cancer screening techniques incorporating the cervical-vaginal cytology. For further studies, it is necessary to determine the level of knowledge of Quilombola population on health-related issues including HPV infection and cervical cancer. This will contribute to the continuous improvement of healthcare coverage among the population and enhance the implementation of cancer care in the state of Maranhão.

Keywords: Human papillomavirus (HPV), Prevalence, Risk factors, Genotypes, Cervical cancer, Pap smear, Quilombola women

\footnotetext{
*Correspondence: cnsd_ma@uol.com.br

'Department of Pathology, Center of Biological and Health Sciences, Federal

University of Maranhão, São Luís, Brazil

${ }^{4}$ Post-graduate Program in Adult and Child Health, Federal University of

Maranhão, São Luís, Brazil

Full list of author information is available at the end of the article
} 


\section{Background}

Cervical cancer $(\mathrm{CC})$ is the third most common cancer among women worldwide, with approximately 528,000 new cases per year, being responsible for the death of 266,000 women each year [1]. According to the Brazilian National Cancer Institute, the estimated number of cases of CC for the year 2014 (and 2015), were approximately 15,590 in Brazil. CC is the second most common neoplasm in the northeast Brazil (18.79 cases/100,000 inhabitants). In Maranhão, annually, 880 new cases are estimated and 200 new cases in São Luís, thus surpassing breast cancer [2]. The prevalence of HPV in Brazil ranges from $16.8 \%$ to $26.8 \%$ in women not stratified by cytology $[3,4]$. In a study on indigenous populations, the prevalence of HPV by polymerase chain reaction (PCR) and hybrid capture was 29.0\%. [5].

Human papillomavirus (HPV) belongs to the Papillomaviridae family, genus Papillomavirus. It is an icosahedral virus, non-enveloped, and about $55 \mathrm{~nm}$ in diameter. The genome consists of a double-stranded circular DNA, containing approximately 7900 base pairs [6]. Thus far, about $200 \mathrm{HPV}$ types (designated with the HPV acronym and an assigned number, as characterized) have been identified [7].

HPVs are classified into low or high oncogenic risk groups, according to their ability to cause malignant lesions including cervical carcinomas. The low-risk types (HPV types: 6, 11, 40, 42, 43 and 44) are associated with the development of benign lesions such as warts, while the high risk types (HPV types: 16, 18, 31, 33, 35, 39, 45, $51,52,56,58,59$ and 66 ) are associated with the process of carcinogenesis. HPV types 16 and 18 are related to more than $70 \%$ of $C C$ cases [8-10].

HPV types 31, 33, 35, 45, 52 and 58 are the most common, but there are large variations in the frequencies [11]. For example, in developed countries, HPV 58, HPV 33 and HPV 45 are listed as the third, fourth, and fifth most prevalent HPV types respectively, when associated with cancer. Among the developing countries, HPV 33, HPV 31, and HPV 45 hold these respective positions [12]. It is estimated that most men and women are infected with at least one subtype of HPV during their sexual life, although with most of the people, the infection neither persists nor progresses to cancer [13].

Persistent HPV infection is a necessary condition for the development of intraepithelial preneoplastic lesions and invasive $\mathrm{CC}$. However, it was demonstrated that, by itself, HPV is not a sufficient cause. HPV requires the association of other co-factors for the development, maintenance, and progression of intraepithelial lesions [14-16]. Several studies have evaluated the risk factors for genital HPV infection. Such risk factors include, the number of sexual partners, early sexual activity, new sexual partner, smoking, prolonged use of oral contraceptives, history of sexually transmitted diseases (STDs) including infection by Chlamydia trachomatis, herpes simplex type 2 and $\mathrm{HIV}$, as well as factors such as immunosuppression and genetic predisposition [17].

The earliest changes of cervical lesions are low-grade cytological abnormalities such as atypical squamous cells of undetermined significance (ASC-US) and low-grade squamous intraepithelial lesion (LSIL). A systematic review of 423 studies showed that HPV-DNA from 48 different types of alpha-papillomavirus HPV was present in $52.1 \%$ of ASC-US and $74.2 \%$ of LSIL lesions [18]. A meta-analysis of 32 studies reported that high-risk HPV were detectable in $43 \%$ of ASC-US and in $76 \%$ of cervical intraepithelial neoplasm grade 1 [19].

Currently, two virus-like particles-based vaccines formed by L1 proteins of HPV 6, -11, -16, and 18 (Gardasil) or HPV 16 and -18 (Cervarix) are available on the market. Both proved to be highly immunogenic vaccines in clinical trials, resulting in $100 \%$ seroconversion in the different studied populations [20, 21].

According to information from the Federation of Associations of the State of Maranhão Municipalities (FAMEM) [22], Maranhão is the Brazilian state with the largest number of Quilombo remnants. The are 642 Quilombo communities, with only 369 recognized by the Palmares Cultural Foundation and the Federal Government with publications in the Official Gazette [23]. Quilombola communities are ethnic and racial groups according to autoallocation criteria, with its own historical background [24]. This history entailed geographical isolation with specific territorial relations, the presumption of black ancestry, monogamous relationships (only between members of Quilombos), and with resistance to historical oppression [24]. Ethnic and racial disparities are seen in CC. NonHispanic black women and Hispanic women have higher incidence and mortality rates than other racial groups [25].

The data about the health of the Quilombola population are scarce, especially in relation to prevalence, genotypes, and risk factors for HPV infection. Therefore, data about the distribution of specific types of HPV in the region and their relationship to the carcinogenic potential of HPV in the diagnosis of associated cytologic abnormalities are important tools to evaluate the behavior of these infections and associated lesions in the post-vaccination period.

The aim of this study was to determine the prevalence and the distribution of HPV genotypes in Quilombola women and to evaluate the risk factors associated with HPV infection.

\section{Materials and methods}

\section{Type and area of study}

This was a cross-sectional study carried out to determine the prevalence of CC and HPV infection in Quilombola 
women from the State of Maranhão, in the Municipalities of São José de Ribamar, Presidente Vargas, Viana, São Luís Gonzaga, Central do Maranhão and Alcântara. The studied Quilombola communities were Juçatuba (São José de Ribamar); Sapucaia, Sororoca, Boa Hora I, Boa Hora II, Cavianã, Cigana, Estiva dos Cotos, Irmã Dorate, Lagoa Grande, Marajá, Pau D'arco and Fincapé (Presidente Vargas); São Cristóvão, Rua Grande, Rua Linares Pinheiros, Rua Santa Luzia and Rua Principal (Viana); Café Pipira, Monte Cristo, Fazenda Velha, Natal, Vale Verde, Santo Antônio da Costa and Antonio Matos (São Luís Gonzaga); São Sebastião (Central do Maranhão) and Mocagituba I, Mocagituba II, Cajueiro, Santo Inácio, Povoado Oitiva, Povoado Castelo, Povoado Raimundo Sú, Novo Belém, Povoado Lisboa, Tubarão and Goiabal (Alcântara).

\section{Study population}

The population selected for this study consisted of 161 Quilombola families (being the sample size estimated for 395 people), aged between 12 and 84 years, recruited from March 2012 to February 2013.

The inclusion criteria were: Quilombola women who have had or still have sexual activities and who spontaneously sought the Cervical Cancer Control Program examination as users of the Unified Health System of the Municipalities of Maranhão, and who signed the free and informed consent term.

Exclusion criteria: hysterectomized Quilombola women, or those subjected to cervical surgery, those with mental deficit (this might undermine their understanding of the questions as well as the answers to complete the specific forms), and women whose samples were with DNA degradation or with unsatisfactory vaginal cervical smear.

\section{Study sample}

The study sample consisted of 395 Quilombola women who underwent cytological examination, PCR and genotyping for HPV detection.

\section{Data collection}

The sample collection was carried out from March 2012 to February 2013. It was preceded at the time of sample collection by an interview using a structured epidemiological questionnaire that included information on sociodemographic characteristics, habits, as well as sexual and reproductive history.

The women underwent careful clinical examination with an inspection of the external genital and perianal region. Secretions of ectocervix and endocervix, taken for cytological examination, were conducted by conventional method. The biologic samples were also immersed in a preserving buffer media and used for HPV-DNA detection by PCR [26] and genotyping by reverse hybridization the Linear Array HPV Genotyping Test kit (Roche Molecular
Systems). The samples were stored in a freezer at $-20{ }^{\circ} \mathrm{C}$ until DNA extraction (in the Biobank of tumors and DNA of the Federal University of Maranhão (UFMA).

\section{Cytological examination}

Cytological smears consisted of ectocervical and endocervical mucous samples (squamo-columnar junction), collected with Ayre's spatula and endocervical brush. The cell smear was held in a glass slide, which was fixed with alcohol and forwarded for staining using the Papanicolau technique at the Nucleus of Basic and Applied Immunology, Department of Pathology of UFMA. All smears were subjected to a strict quality control adopted by the laboratory. This was done by reviewing all negative smears for cervical cytological abnormalities by three cytopathologists. The results of suitability of the samples and the degree of cervical abnormalities were interpreted according to the Bethesda System revised in 2001 [27].

\section{HPV analysis}

The extraction of the genomic DNA from the samples was performed using the QIAamp DNA FFPE Tissue Purification Kit (QIAGEN ${ }^{\circ}$ ) according to the extraction protocol suggested by the manufacturer.

The Nested PCR reactions were performed by using primers PGMY09 and PGMY11 for the first round, and primers GP + 5 and GP + 6 for the second round $[26,28]$.

After denaturation, the material was applied to a nylon strip containing immobilized probes for two different concentrations of $\beta$-globin, $19 \mathrm{HPV}$ genotypes with high oncogenic risk $(16,18,26,31,33,35,39,45,51,52,53$, $56,58,59,66,68,69,73$ and 82 ) and 18 types of HPV with low oncogenic risk $(6,11,40,42,54,55,61,62,64$, 67, 70, 71, 72, 81, 83, 84, IS39 and CP6108).

\section{Statistical analysis}

The data were analyzed using the statistical program SPSS for Windows 20.0 (SPSS Inc., Chicago, USA). Initially, exploratory (descriptive) analyzes of the numerical variables (age, age at menarche and the onset of sexual activity), calculating the maximum, minimum, medians and standard deviation were done. Association between HPV types and cytology results for women with single infection was performed with the chi-square test. To evaluate the association between HPV types and sociodemographic and clinical variables, a nonparametric ANOVA was performed using the Kruskal Wallis test. In all tests, the significance cut off level $(\alpha)$ was $5 \%$ and the results were considered significant when $p<0.05$.

\section{Ethical aspects}

This project was submitted and approved by the institutional review board (IRB) of the University Hospital of Federal University of Maranhão and the IRB of the 
Federal University of Maranhão. To participate, the women signed the free and informed consent term. For the minors/children enrolled in this study, the objectives were explained to them and they signed the agreement consent (Resolution 466/12 of the National Health Council and its complementary).

\section{Results}

A total of 395 women were included in the study, with $27.8 \%$ (110) being less than 30 years of age. The age of patients ranged from 12 to 84 years, with a mean age of $41.3 \pm 14.4$ years. Most women, 261 (66.0\%) had finished elementary school, were married, 241 (61.0\%) and by race, most, 180 (45.5\%) were brown (Table 1$)$.

Table 1 shows the behavioral characteristics of the participants. The minimum and maximum age at menarche was 9 years and 17 years respectively, with a median age of 13 years \pm 1.5 years. The earliest sexual initiation was by 10 years, with only case of sexual initiation by 43 years of age, with a median of 16.6 years \pm 3.1 .

Among the 395 women, 33 (8.4\%) had cytological abnormalities, which included 5 (15.2\%) women with 'atypical squamous cells, cannot exclude high-grade squamous intraepithelial lesion [HSIL]' (ASC-H), 11 (33.3\%) women with 'ASC-US, 10 (30.3\%) women with HSIL, and 7 (21.2\%) women with LSIL.

The overall prevalence of HPV was $12.6 \%$ (50/395). In Table 2, among the 33 women who had cytological abnormalities, $12(36.4 \%)$ were positive for HPV. From the 395 women, studied, 336 had diagnoses of inflammation, out of which $35(10.4 \%)$ were positive for HPV. For ASC-H, ASC-US, HSIL and LSIL, HPV infection rate were $40.0 \%$ (2/5), $18.2 \%$ (2/11), 60.0\% (6/10) and $28.2 \%$ $(2 / 7)$ respectively (Table 2$)$. There was a statistically significant association between the presence of cytological abnormalities in cervical smears and the presence of HPV $(p<0.001)$.

Among the HPV types, the most prevalent genotypes were $68(26.0 \%$ - 13/50), 58 and 52 with 20.0\% (10/50) each, $31(10.0 \%-5 / 50)$ and $62(8.0 \%-4 / 50)$. Only $6.0 \%$ $(3 / 50)$ of the cases were positive for HPV-61 (Table 3$)$.

Regarding the presence of HPV in different cytologic findings, the high oncogenic risk type were more frequent (78.0\%, 39/50) compared with the low oncogenic risk type (22.0\% -11/50). Among those diagnosed with an abnormality, the prevalence of HPV infection was 24.0\% (12/ $50)$. The highest prevalence was reported with HSIL (42.0\%), followed by LSIL (21.0\%) and ASC-US (21.0\%). In all diagnoses, simple infections were more frequent than multiple (Table 3).

Table 4 shows the prevalence of HPV in women with different cytologic findings, stratified by age group. In women younger than 30 years, positivity for HPV ranged from $23.2 \%(25 / 108)$ in women with inflammatory smears to $100 \%$ in women with LSIL and HSIL findings. There was a significant association between HPV positivity and cytologic abnormalities detection in these age groups: younger than 30 years $(p=0.02), 31-40$ years $(p=0.0009), 41$ to 50 years $(p=0.03)$ and 51 and 60 years $(p=0.0003)$. Only among HPV-positive women, aged over 60 years, were there no statistically significant association with the detection of cytological abnormalities $(p=0.12)$.

In Table 5, with sociodemographic variables, only the municipality of origin showed significant association with HPV positivity $(p<0.0001)$. The remaining sociodemographic variables (age, education, marital status, and race) showed no significant association with HPV positivity.

The behavioral predictors of HPV, at the univariate level, are shown in Table 6. None of the variables analyzed (onset of sexual activity, number of partners, age at menarche, number of pregnancies, STD signs, use of contraceptive, hygiene frequency, performing of Pap test, result of the inspection of the cervix, drinking and smoking), showed significant association with HPV positivity except the number of partners $(p=0.01)$.

\section{Discussion}

In Brazil, the Black population experience higher cancer mortality rates compared to the general population. This is probably a consequence of inequities in the social, economic, political, and health factors. This population is faced with unequal experiences at birth, in life, during illness and in death [29]. Quilombo communities fall within this context, as they are presumed to have Black ancestry, and they are also presumed to have important social risk experiences such as the historical process of expropriation of culture and rights. This led to social and health inequality, the impact of which is reflected in poor health indicators among this population [30]. Since the non-realization of the importance of Pap smear examination is associated among other things with the inequalities in the access to and the utilization of health services, it is important to consider the preventive measures for $\mathrm{CC}$ as requiring the improvement of the living conditions and the increased supply and access to health services in Quilombo communities [29].

The overall prevalence of HPV can vary depending on the technique used, as well as the population and the region studied. In this study, the prevalence of HPV infection in Quilombola women was $12.6 \%$ by hybridization technique. Different results were found in various studies including Akarolo-Anthony et al. (2014), which showed an overall prevalence of $37 \%$ in Nigerian women [31], and Watson-Jones et al. (2013), with a prevalence of $74 \%$ among women in Tanzania [32]. Cervantes et al. (2003), in a study on indigenous peoples of the Bolivian Amazon, found a prevalence of $5.9 \%$ of HPV DNA [33]. 
Table 1 Sociodemographic and behavioral characteristics of Quilombola women

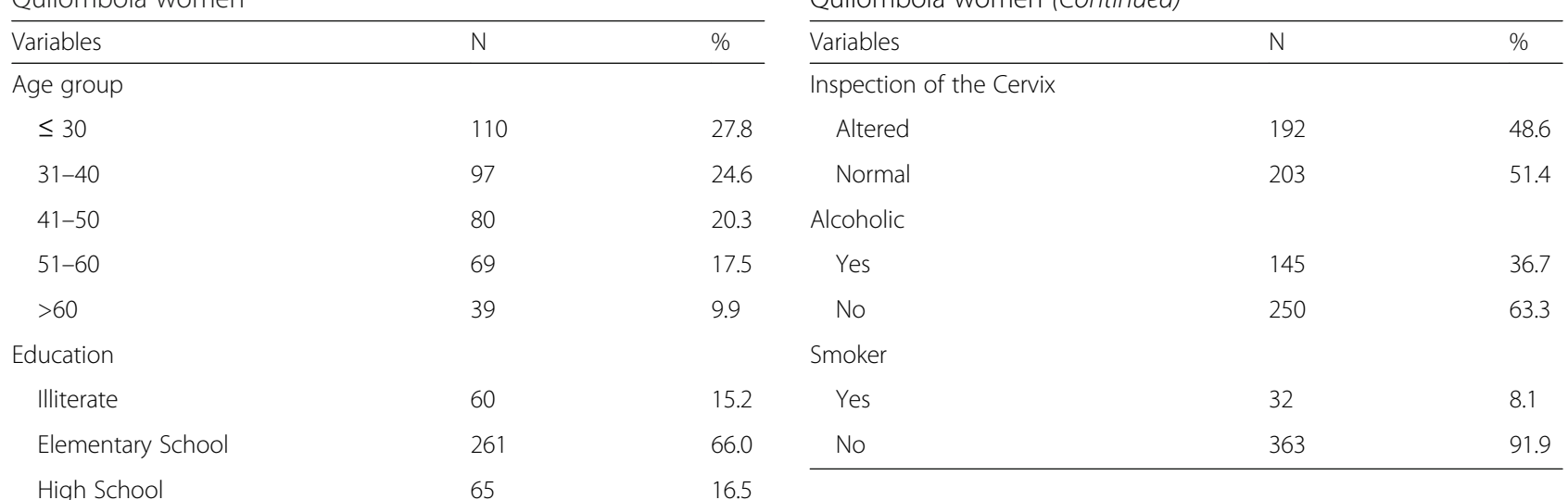

Higher Education

Marital Status

Married

Other

Race

White
Black
Brown

Not informed

Beginning of sexual activity

$\leq 15$ years

$>15$ years

Number of partners

$$
\text { One }
$$

More than one

Age of Menarche

$$
\leq 12 \text { years }
$$

$>12$ years

$N^{\circ}$ pregnancies

Up to one

More than one

\section{STD Signs}

No

Yes

Use of contraceptive

Yes

No

\section{0}

Genital hygiene frequency

$$
\text { Once a day }
$$

More than once a day

Performing of Papanicolau examination

Yes

5

.

2.3

61.0

39.0

6.6

32.4

45.5

15.5

38.4

61.6

45.3

54.7

41.0

59.0

17.5

82.5

70.4

29.6

17.7

82.3

17.7

82.3

14.7

85.3
Table 1 Sociodemographic and behavioral characteristics of Quilombola women (Continued)

Pinto et al. (2011) investigated the prevalence and risk factors for genital infection with HPV in women from rural and urban areas in two different regions of the Eastern Brazilian Amazon and found an overall HPV infection prevalence of $14.6 \%$ (15.0\% in urban and $14.2 \%$ in rural women), similar to our study [34].

Some women had multiple HPV infections in this study, and these occurred more frequently with HPV 68, with a total of $71 \mathrm{HPV}$ types among HPV positive women, and among these, 50 (69.4\%) were of high oncogenic risk. Of the $25 \mathrm{HPV}$ types found in this study, HPV 68 was the most prevalent $(26.0 \%)$, followed by HPV 58 and 52 (20.0\%) and HPV 31 (10.0\%).

A study conducted in France showed HPV 16 to be most prevalent, followed by HPV 53 and 31 [35]. Study in Vietnam showed the HPV types 16, 18 and 58 as most prevalent [14]. Xue et al. (2015) found that HPV types 16, 52 and 58 were more prevalent, while HPV 68 was only the eighth most prevalent [36].

Goldman et al. (2013) observed that the presence of HPV 68 occurred at a rate four times higher, than expected, in multiple infections. Thus, this indicates the existence of an interaction between HPVs of high oncogenic risk, especially between types $31 / 68$, 51/68 and 33/ 58. These authors suggested that some virus genotypes act as co-factors in the infection by other types, demonstrating a new possible risk factor [37].

Considering the prevalence of HPV in women with different cytologic findings in this study, age group (particularly less than 30 years) showed important influence on HPV positivity and the detection of cytologic abnormalities. Thus, these results indicate that HPV testing is useful in women over 30 years, who are more likely to be carriers of significant cervical lesions. According to Akarolo-Anthony et al. (2014), the age group most affected by HPV infection were those aged less than 30 years, while a decline were shown in women over 45 years of age, thus corroborating the findings of this study [31]. In Fiji, in the studied population, with age, a 
Table 2 HPV prevalence by cytologic abnormalities in Quilombola women

\begin{tabular}{llll}
\hline \multirow{2}{*}{ Cytological Abnormalities } & \multicolumn{1}{l}{ HPV } & Positive $\mathrm{n}(\%)$ & Total $\mathrm{n}(\%)$ \\
\cline { 2 - 4 } ASC-H & Negative $\mathrm{n}(\%)$ & $2(40.0)$ & $5(100.0)$ \\
ASC-US & $3(60.0)$ & $2(18.2)$ & $11(100.0)$ \\
HSIL & $9(81.8)$ & $6(60.0)$ & $10(100.0)$ \\
LSIL & $4(40.0)$ & $2(28.6)$ & $7(100.0)$ \\
Inflammation & $5(71.4)$ & $35(10.4)$ & $336(100.0)$ \\
Atrophy & $301(89.6)$ & $3(11.6)$ & $26(100.0)$ \\
Total & $23(88.4)$ & $50(12.6)$ & $395(100.0)$ \\
\hline
\end{tabular}

ASC-H - (atypical squamous cells cannot exclude high-grade squamous intraepithelial lesions)

ASC-US - (atypical squamous cells of undetermined significance)

HSIL - (high-grade intraepithelial lesion)

LSIL - (low-grade squamous intraepithelial lesion)

Table 3 Distribution of HPV genotypes in the cytologic findings of Quilombola women

\begin{tabular}{|c|c|c|c|c|c|c|c|}
\hline \multirow[t]{2}{*}{ HPV Types } & \multicolumn{7}{|c|}{ Cytological Abnormalities } \\
\hline & ASC-H & ASC-US & $\mathrm{HSIL}$ & Inflammation & LSIL & Atrophy & Total \\
\hline HPV High risk & $\mathrm{n}(\%)$ & $\mathrm{n}(\%)$ & $\mathrm{n}(\%)$ & $\mathrm{n}(\%)$ & n (\%) & $\mathrm{n}(\%)$ & $\mathrm{n}(\%)$ \\
\hline 16 & - & - & 1 & - & - & - & 1 \\
\hline 18 & - & - & 1 & 1 & - & - & 2 \\
\hline 31 & - & - & - & 4 & 1 & - & 5 \\
\hline 33 & - & - & - & 1 & - & - & 1 \\
\hline 39 & - & - & - & 1 & - & - & 1 \\
\hline 45 & - & - & - & 2 & - & - & 2 \\
\hline 51 & - & - & - & 1 & - & - & 1 \\
\hline 52 & - & 1 & 2 & 6 & - & 1 & 10 \\
\hline 56 & - & - & - & 1 & - & - & 1 \\
\hline 58 & - & 1 & 2 & 6 & - & 1 & 10 \\
\hline 59 & - & - & - & - & - & 1 & 1 \\
\hline 66 & - & - & - & 1 & - & - & 1 \\
\hline 68 & - & 1 & - & 11 & - & 1 & 13 \\
\hline 70 & - & - & - & 2 & - & - & 2 \\
\hline 73 & 1 & - & - & - & - & 1 & 2 \\
\hline \multicolumn{8}{|l|}{ HPV Low risk } \\
\hline 53 & - & - & - & 2 & - & - & 2 \\
\hline 54 & - & - & - & 2 & - & - & 2 \\
\hline 55 & - & - & - & 1 & - & - & 1 \\
\hline 61 & - & - & - & 2 & 1 & - & 3 \\
\hline 62 & - & - & - & 3 & 1 & - & 4 \\
\hline 71 & - & - & - & - & - & 1 & 1 \\
\hline 72 & - & - & - & 1 & - & - & 1 \\
\hline 84 & - & - & 1 & - & - & - & 1 \\
\hline IS39 & 1 & - & 1 & - & - & - & 2 \\
\hline CP6108 & - & - & - & - & - & 1 & 1 \\
\hline Total of positives & 2 & 3 & 8 & 49 & 3 & 7 & $71^{*}$ \\
\hline
\end{tabular}

*This number refers to simple and multiple infections. Among 6 multiple infections of the virus 68,3 were associated with the virus type 52

ASC-US, atypical squamous cells of undetermined significance; LSIL: low-grade squamous intraepithelial lesion; ASC-H: atypical squamous cells cannot exclude high-grade squamous intraepithelial lesion; HSIL: high-grade squamous intraepithelial lesion 
Table 4 HPV prevalence by cytologic findings and according to age groups in Quilombola women

\begin{tabular}{|c|c|c|c|}
\hline \multirow[b]{2}{*}{ Cytologic Finding } & \multicolumn{2}{|l|}{ HPV Detection } & \multirow[t]{2}{*}{$p$} \\
\hline & Negative n (\%) & Positive $\mathrm{n}(\%)$ & \\
\hline \multicolumn{4}{|c|}{ Age group (<30 years) } \\
\hline ASC-US & $3(60.0)$ & $2(40.0)$ & 0.02 \\
\hline HSIL & - & $2(100.0)$ & \\
\hline LSIL & - & $2(100.0)$ & \\
\hline Inflammation & $83(76.8)$ & $25(23.2)$ & \\
\hline Atrophy & $2(100.0)$ & - & \\
\hline Total & $88(74.0)$ & $31(26.0)$ & \\
\hline \multicolumn{4}{|c|}{ Age group (31-40 years) } \\
\hline ASC-H & - & $2(100.0)$ & 0.0009 \\
\hline ASC-US & $2(100.0)$ & - & \\
\hline HSIL & $1(100.0)$ & - & \\
\hline LSIL & $2(50.0)$ & $2(50.0)$ & \\
\hline Inflammation & 77 (84.6) & $14(15.4)$ & \\
\hline Atrophy & - & $2(100.0)$ & \\
\hline Total & $82(80.4)$ & $20(19.6)$ & \\
\hline \multicolumn{4}{|c|}{ Age group (41-50 years) } \\
\hline $\mathrm{ASC}-\mathrm{H}$ & $2(100.0)$ & - & 0.03 \\
\hline ASC-US & $2(66.7)$ & $1(33.3)$ & \\
\hline HSIL & - & $2(100.0)$ & \\
\hline LSIL & $1(100.0)$ & - & \\
\hline Inflammation & $62(85.0)$ & $11(15.0)$ & \\
\hline Atrophy & $1(50.0)$ & $1(50.0)$ & \\
\hline Total & $68(82.0)$ & $15(18.0)$ & \\
\hline \multicolumn{4}{|c|}{ Age group (51-60 years) } \\
\hline $\mathrm{ASC}-\mathrm{H}$ & - & $1(100.0)$ & 0.0003 \\
\hline ASC-US & $1(100.0)$ & - & \\
\hline HSIL & $1(20.0)$ & $4(80.0)$ & \\
\hline Inflammation & 49 (90.7) & $5(9.3)$ & \\
\hline Atrophy & $11(73.3)$ & $4(26.7)$ & \\
\hline Total & $62(81.5)$ & $14(18.5)$ & \\
\hline \multicolumn{4}{|c|}{ Age group (>60 years) } \\
\hline ASC-US & - & $1(100.0)$ & 0.12 \\
\hline LSIL & $1(100.0)$ & - & \\
\hline Inflammation & 19 (82.6) & $4(17.4)$ & \\
\hline Atrophy & $10(90.9)$ & $1(9.1)$ & \\
\hline Total & $20(80.0)$ & $5(20.0)$ & \\
\hline
\end{tabular}

ASC-US, atypical squamous cells of undetermined significance; LSIL: low-grade squamous intraepithelial lesion; ASC-H: atypical squamous cells cannot exclude high-grade squamous intraepithelial lesion; HSIL: high-grade squamous intraepithelial lesion;

decline of HPV infection rates were shown, and these ranged from $35.8 \%$ among women aged less than 25 years to $18.6 \%$ in women aged $55-64$ years [38].
Table 5 Univariate analysis of sociodemographic factors associated with HPV infection in Quilombola women

\begin{tabular}{|c|c|c|c|}
\hline \multirow[b]{2}{*}{ Variables } & \multicolumn{2}{|c|}{ Detection of HPV } & \multirow[t]{2}{*}{$p$} \\
\hline & Negative n (\%) & Positive n (\%) & \\
\hline \multicolumn{4}{|l|}{ Age } \\
\hline$\leq 30$ years & $91(82.7)$ & 19 (17.3) & \multirow[t]{5}{*}{0.65} \\
\hline 31 to 40 years & $87(89.7)$ & $10(10.3)$ & \\
\hline 41 to 50 years & $72(90.0)$ & $08(10.0)$ & \\
\hline 51 to 60 years & $60(86.7)$ & $09(13.3)$ & \\
\hline$>60$ years & 35 (89.7) & $04(10.3)$ & \\
\hline \multicolumn{4}{|l|}{ Education } \\
\hline Illiterate & $51(85.0)$ & $09(15.0)$ & \multirow[t]{4}{*}{0.72} \\
\hline Elementary School & $231(88.5)$ & $30(11.5)$ & \\
\hline High School & $56(86.1)$ & 09 (13.9) & \\
\hline Higher Education & $7(77.7)$ & $02(22.3)$ & \\
\hline \multicolumn{4}{|l|}{ Origin } \\
\hline Alcântara & $96(95.0)$ & $05(5.0)$ & \multirow[t]{6}{*}{$<0.0001$} \\
\hline Central do Maranhão & $45(90.0)$ & $05(10.0)$ & \\
\hline Presidente Vargas & $46(73.0)$ & $17(27.0)$ & \\
\hline São José de Ribamar & $91(90.0)$ & $10(10.0)$ & \\
\hline São Luís Gonzaga & $40(74.0)$ & $14(26.0)$ & \\
\hline Viana & $25(96.1)$ & $01(3.9)$ & \\
\hline \multicolumn{4}{|l|}{ Marital status } \\
\hline Single & $100(84.0)$ & $19(16.0)$ & \multirow[t]{4}{*}{0.24} \\
\hline Married & 216 (89.6) & $25(10.4)$ & \\
\hline Divorced & 05 (83.3) & $01(16.7)$ & \\
\hline Widow & $24(82.7)$ & $05(17.3)$ & \\
\hline \multicolumn{4}{|l|}{ Race } \\
\hline White & $21(80.7)$ & $05(19.3)$ & \multirow[t]{4}{*}{0.57} \\
\hline Black & $109(85.1)$ & $19(14.9)$ & \\
\hline Brown & 159 (88.3) & $21(11.7)$ & \\
\hline Not informed & $56(91, .8)$ & $05(8.2)$ & \\
\hline
\end{tabular}

In a study by Foliaki et al. (2014), the positivity for at least one HPV genotype was $24.0 \%$ among 1244 women studied, however, HPV 16 was the most prevalent genotype, while HPV 68 was present in only $3(0.2 \%)$ of the infected women. From the HPV positive cases, 70.1\% had only one viral genotype, while $29.9 \%$ had multiple infections. HPV genotypes most often involved in multiple infections were of the high oncogenic risk [38].

Among the 33 women who had cytological abnormalities, $36.4 \%$ were HPV positive. Among those diagnosed with inflammation, $10.4 \%$ were HPV positive. For ASC$\mathrm{H}, \mathrm{ASC}-\mathrm{US}, \mathrm{HSIL}$ and LSIL, HPV infection rate were $40.0 \%, 18.2 \%, 60.0 \%$ and $28.2 \%$ respectively. There was a statistically significant association between the presence of cytological abnormalities in cervical smears and the presence of HPV $(p<0.001)$. Marks et al. (2015) found a 
Table 6 Univariate analysis of behavioral factors associated with HPV infection in Quilombola women

\begin{tabular}{|c|c|c|c|}
\hline \multirow{2}{*}{$\begin{array}{l}\text { Behavioral } \\
\text { variables }\end{array}$} & \multicolumn{2}{|c|}{ Detection of HPV } & \multirow[t]{2}{*}{$\mathrm{p}$} \\
\hline & Negative n (\%) & Positive n (\%) & \\
\hline \multicolumn{4}{|c|}{ Onset of sexual activity } \\
\hline$\leq 15$ years & $126(82.9)$ & $26(17.1)$ & \multirow[t]{2}{*}{0.65} \\
\hline$>15$ years & $219(90.1)$ & $24(9.9)$ & \\
\hline \multicolumn{4}{|c|}{ Number of partners } \\
\hline One & $158(88.2)$ & $21(11.8)$ & \multirow[t]{2}{*}{0.01} \\
\hline More than one & $187(86.5)$ & $29(13.5)$ & \\
\hline \multicolumn{4}{|l|}{ Age at menarche } \\
\hline$\leq 12$ years & $141(87.0)$ & $21(13.0)$ & \multirow[t]{2}{*}{0.22} \\
\hline$>12$ years & $204(87.5)$ & $29(12.5)$ & \\
\hline \multicolumn{4}{|c|}{ Number of pregnancies } \\
\hline Up to one & $63(91.3)$ & $06(8.7)$ & \multirow[t]{2}{*}{0.32} \\
\hline More than one & $282(86.5)$ & $44(13.5)$ & \\
\hline \multicolumn{4}{|l|}{ STD Signs } \\
\hline No & $234(84.1)$ & $44(14.9)$ & \multirow[t]{2}{*}{0.56} \\
\hline Yes & $111(94.8)$ & $06(5.2)$ & \\
\hline \multicolumn{4}{|c|}{ Use of contraceptive } \\
\hline Yes & $53(75.7)$ & $17(24.3)$ & \multirow[t]{2}{*}{0.47} \\
\hline No & $292(89.8)$ & $33(10.2)$ & \\
\hline \multicolumn{4}{|c|}{ Frequency of genital hygiene } \\
\hline Once & $58(82.8)$ & $12(17.2)$ & \multirow[t]{2}{*}{0.30} \\
\hline More than once & $287(88.3)$ & $38(11.7)$ & \\
\hline \multicolumn{4}{|c|}{ Performing of Pap test } \\
\hline No & $49(84.4)$ & 09 (15.6) & \multirow[t]{2}{*}{0.17} \\
\hline Yes & $296(87.8)$ & $41(12.2)$ & \\
\hline \multicolumn{4}{|c|}{ Inspection of the Cervix } \\
\hline Altered & $169(88.0)$ & $23(12.0)$ & \multirow[t]{2}{*}{0.59} \\
\hline Normal & $176(86.7)$ & 27 (13.3) & \\
\hline \multicolumn{4}{|l|}{ Alcohol } \\
\hline Yes & 127 (87.6) & 18 (12.4) & \multirow[t]{2}{*}{0.99} \\
\hline No & $218(87.2)$ & 32 (12.8) & \\
\hline \multicolumn{4}{|l|}{ Smoker } \\
\hline Yes & $25(78.1)$ & 07 (21.9) & \multirow[t]{2}{*}{0.98} \\
\hline No & $320(88.1)$ & 43 (11.9) & \\
\hline
\end{tabular}

much higher prevalence (43.8\%) of HPV infection among women diagnosed with inflammation, $36.5 \%$ diagnosed with ASC-US, 80.9\% of women diagnosed with LSIL and $71.5 \%$ of women with the diagnosis of HSIL [39]. The HPV type 68, in single or multiple infections, was detected mainly in women whose smears were considered inflammatory. The high-risk types of HPV 58, 52, 18 and 16 were detected in Quilombola women with cytological diagnosis of HSIL, agreeing with other findings in the literature $[35,39,40]$.
Based on the presence of HPV in different cytologic findings, the high oncogenic risk types were more frequent $(78.0 \%)$ than those of low oncogenic risk (22.0\%). This has important implications for the clinical care of women with the high oncogenic risk. For those diagnosed with an abnormality, the prevalence of HPV infection was $24.0 \%$, and was highest with HSIL (42.0\%).

In relation to sociodemographic factors and HPV infection, only the municipality of origin was significantly associated with positivity for HPV $(p<0.0001)$. AkaroloAnthony et al. (2014), in studying Nigerian women, also found no association between sociodemographic factors (education, age, marital status) and HPV infection [31]. This may be related to the characteristics of the study population including, geographical isolation, conservative habits as well as non-consumption of alcohol and tobacco.

In this study, there was significant association with HPV positivity only in relation to the number of partners $(p=0.01)$. Work carried out in Guinea by Keita et al. (2009) also demonstrated a significant association between the number of partners and HPV infection [41].

A limitation of the study is the approach used for the collection of data on risk factors used to determine how HPV was acquired and maintained, since the statistical associations were made solely based on the information reported by women. Therefore, another limitation is that the study lacks an adequate comparison group.

\section{Conclusions}

This study provides a regional estimate on the prevalence of HPV infection among Quilombola women. It highlighted the higher prevalence of HPV type 68. This virus type can contribute to an increase in cervical carcinogenesis related to specific HPV genotypes.

It is believed that the findings of this study can foster the development of strategies aimed at enhancing the health of the Quilombola women towards the prevention and management of specific HPV infection in view of the particularities of this group. Greater knowledge, on the part of women, on the mode of HPV acquisition, risk factors and the frequency of HPV infection in different age and population groups are crucial. This is because, such knowledge would contribute to a greater perception of their risk of developing cervical preneoplastic lesions and therefore influence their continued adherence to screening strategies. It may also encourage changes in HPV risk behavior and lifestyle.

\section{Abbreviations}

ASC-H: atypical squamous cells cannot exclude high-grade squamous intraepithelial lesions; ASC-US: atypical squamous cells of undetermined significance; CC: Cervical cancer; CIN 1: Cervical Intraepithelial Neoplasm grade 1; DEPAT: Department of Pathology; DNA: deoxyribonucleic acid; HIV: Human Immunodeficiency Virus; HPV: Human Papillomavirus: HSIL: high-grade intaepithelial lesion; INCA: Brazilian National Cancer 
Institute; LSIL: low-grade squamous intraepithelial lesion; NIBA: Nucleum of Basic and Applied Immunology; PCCU: Cervical Cancer Control Program; PCR: polymerase chain reaction; PGMY 09/11: primers; STD: Sexually transmitted diseases; UCM: universal collection medium; UFMA: Federal University of Maranhão; VLP: virus-like particles

\section{Acknowledgements}

To the National Institute of Cancer, Division of Genetics for the genotyping tests. To the Basic and Applied Immunology Center of Federal University of Maranhão for reviewing the blades of cytological examinations and to the Biobank of tumors and DNA of Maranhão for conducting the molecular biology tests. To FAPEMA for funding this research.

\section{Funding}

The funding for this research was obtained via the Project 01363/09 - FAPEMA Notice MS/CNPq/FAPEMA No. 012/2009, Research Program for the SUS: shared management in health - PPSUS.

\section{Availability of data and materials}

Data and materials are available at Nucleus of Basic and Applied Immunology from Federal University of Maranhão.

\section{Authors' contributions}

FCBV and JEB performed the experiments under the supervision of MDSBN and LMOB. MACNS and MDSBN contributed to the study design, participated in the interpretation of data, drafted, and critically revised the manuscript. MACNS, MCLB, GFBB, GMCV, RCCB and WEMF analyzed and assisted in the interpretation of the data and assisted in the drafting of the manuscript. GFBB and GMCV contributed to the interpretation of the data and critically revised the manuscript. MACNS assisted in the data acquisition and interpretation. All the authors analyzed and interpreted the data. MACNS and MDSBN wrote the manuscript draft, which was read and edited by all the authors. All authors read and approved the final version of the manuscript.

\section{Ethics approval and consent to participate}

This project was submitted and approved by approved by the IRB of the of the University Hospital of Federal University of Maranhão under the number $233 / 2011$. To continue the research, the request for extension of the project duration was submitted to and approved by the IRB of the Federal University of Maranhão, protocol number 785.413/2014.

\section{Consent for publication}

To participate, the women signed the Free and Informed Term of Consent. Of the minors/children enrolled in this study, the objectives were explained and they signed the Agreement Consent and their parents or guardians signed the Free and Informed Term of Consent.

\section{Competing interests}

The authors declare that they have no competing interests.

\section{Publisher's Note}

Springer Nature remains neutral with regard to jurisdictional claims in published maps and institutional affiliations.

\section{Author details}

${ }^{1}$ Department of Pathology, Center of Biological and Health Sciences, Federal University of Maranhão, São Luís, Brazil. ²Department of Morphology, Center of Biological and Health Sciences, Federal University of Maranhão, São Luís, Brazil. ${ }^{3}$ Federal University of Maranhão, São Luís, Brazil. ${ }^{4}$ Post-graduate Program in Adult and Child Health, Federal University of Maranhão, São Luís, Brazil. ${ }^{5}$ Department of Medicine I, Center of Biological and Health Sciences, Federal University of Maranhão, São Luís, Brazil. ${ }^{6}$ Department of Medicine III, Center of Biological and Health Sciences, Federal University of Maranhão, São Luís, Brazil. ${ }^{7}$ Núcleo de Imunologia Básica e Aplicada, Avenida dos Portugueses, 1966, Bacanga. Prédio do CCBS, Bloco 3, Sala 3A, São Luís - MA CEP 65080-805, Brazil.
Received: 15 September 2016 Accepted: 15 December 2017 Published online: 02 January 2018

\section{References}

1. World Health Organization (WHO) - Globocan 2012. Cancer incidence and mortality worldwide: IARC Cancer Base no. 10 [internet]. Lyon, France: International Agency for Research on Cancer; 2015.

2. Brasil. Ministério da Saúde. Secretaria Nacional de Assistência à Saúde. Instituto Nacional de Câncer. Coordenação de Prevenção e Vigilância de Câncer. Estimativas 2014: Incidência de Câncer no Brasil: INCA: Rio de Janeiro; 2014.

3. Trottier H, Mahmud S, Costa MC, Sobrinho JP, Duarte-Franco E, Rohan TE, et al. Human papillomavirus infections with multiple types and risk of cervical neoplasia. Cancer Epidemiol Biomark Prev. 2006;15(7):1274-80.

4. Krambeck WM, Cadidé RM, Dalmarco EM, de Cordova CMHPV. Detection and genotyping as an earlier approach in cervical cancer screening of the female genital tract. Clin Exp Obstet Gynecol. 2008;35(3):175-8.

5. Brito EB, Silva ID, Stávale JN, Taromaru E, Menezess RC, Martins SJ. Amerindian women of the Brazilian Amazon and STD. Eur J Gynaecol Oncol. 2006;27(3):279-81.

6. zur Hausen $\mathrm{H}$. Papillomaviruses and cancer: from basic studies to clinical application. Nat Rev Cancer. 2002;2(5):342-50.

7. de Villiers EM. Cross-roads in the classification of papillomaviruses. Virology. 2013:445(1-2):2-10.

8. IARC. Monographs On the evaluation of carcinogenic risks to humans, volume 100B: a review of human carcinogens: biological agents: Lyon: International Agency for Research on Cancer; 2012

9. Muñoz N, Bosch FX, de Sanjose S, Herrero R, Castellsague X, Shah KV, Snijders PJ, Meijer CJ. Epidemiologic classification of human papillomavirus types associated with cervical cancer. N Engl J Med. 2003;348:518-27.

10. de Villiers EM, Fauquet C, Broker TR, Bernard HU. Zur Hausen H. Classification of papillomaviruses. Virology. 2004;324:17-27.

11. Ferlay J, Shin HR, Bray F, Forman D, Matheus C, Parkin DM. GLOBOCAN 2008, Cancer Incidence and Mortality Worldwide: IARC CancerBase $n^{\circ} 10$ (Internet). Lyon, France: International Agency for Research on Cancer; 2010. Availabe from: http://globocan.iarc.fr.

12. Clifford G, Franceschi S, Diaz M, Muñoz N, Villa LL. Chapter 3: HPV typedistribution in women with and without cervical neoplastic diseases. Vaccine. 2006;24(Suppl 3):S26-34

13. Schiffman $M$, Rodriguez AC, Chen Z, Wacholder S, Herrero R, Hildesheim A, et al. A population-based prospective study of carcinogenic human papillomavirus (HPV) variant lineages, viral persistence, and cervical neoplasia. Cancer Res. 2010;70(8):3159-69.

14. Bosch FX, Burchell AN, Schiffman M, Giuliano AR, de Sanjose S, Bruni L, et al. Epidemiology and natural history of human papillomavirus infections and type-specific implications in cervical neoplasia. Vaccine. 2008;26(Suppl 1):K1-16.

15. Munoz N, Castellsague X, de Gonzalez AB, Gissmann L. Chapter 1: HPV in the etiology of human cancer. Vaccine. 2006;24(Suppl 3):S3/1-S3/10.

16. Dunne EF, Markowitz LE. Genital human papillomavirus infection. Clin Infect Dis. 2006;43(5):624-9.

17. Tran LT, Tran LT, Bui TC, Le DT, Nyitray AG, Markham CM. Risk factors for high-risk and multi-type human papillomavirus infections among women in ho chi Minh City, Vietnam: a cross-sectional study. BMC Womens Health. 2015 Dec;15:172.

18. Bzhalava D, Guan P, Franceschi S, Dillner J, Clifford GA Systematic review of the prevalence of mucosal and cutaneous human papillomavirus types. Virology. 2013:445(1-2):224-31.

19. Arbyn M, Martin-Hirsch P, Buntinx F, Van Ranst M, Paraskevaidis E, Dillner J. Triage of women with equivocal or low-grade cervical cytology results: a meta-analysis of the HPV test positivity rate. Cell. Mol Med. 2009;13(4):648-59.

20. Adams M, Jasani B, Fiander A. Human papilloma virus (HPV) prophylactic vaccination: challenges for public health and implications for screening. Vaccine. 2007;25:3007-13.

21. Villa LHPV. Prophylactic vaccination: the first years and what to expect from now. Cancer Lett. 2011;305(2):106-12

22. Federação das Associações dos Municípios do Estado do Maranhão (FAMEM).Comunidades quilombolas do Estado do Maranhão, 2007. Disponível em:http://www.cpisp.org.br/comunidades/html/i_oque.html.

23. Brasil. Ministério da Cultura. Fundação Cultural Palmares (Internet). Comunidades Quilombolas, 2012. Disponivel em: http://www.palmares.gov. br/?page_id =88. 
24. Cardoso LFC. Sobre imagens e quilombos: notas a respeito da construção da percepção acerca das comunidades quilombolas. R Est Pesq Educ. 2010;12(1):11-20.

25. U.S. Cancer Statistics Working Group. United States Cancer Statistics: 19992006 incidence and mortality web-based report. 2010. Retrieved from http://www.cdc.gov/uscs.

26. Gravitt PE, Peyton CL, Alessi TQ, Heeler CM, Coutleé F, Hildesheim A, Schiffman MH, Scott DR, Apple RJ. Improved amplification of genital human papillomaviruses. J Clin Microbiol. 2000;38:357-61.

27. Solomon D, Davey D, Kurman R, Moriarty A, O'Connor D, Prey M, et al. The 2001 Bethesda system: terminology for reporting results of cervical cytology. JAMA. 2002 Apr 24;287(16):2114-9.

28. Manos MMT, Wright DK, Lewis AJ, Broker TR, Wolinsky SM. The use of polymerase chain reaction amplification for the detection of genital human papillomavirus. Cancer cell Mol Diagnost hum. Cancer. 1989;7:209-14.

29. Lopes F. Experiências desiguais ao nascer, viver, adoecer e morrer: tópicos em saúde da população negra no Brasil. In: Brasil, Fundação Nacional de Saúde. Saúde da população negra no Brasil: contribuições para a promoção da equidade. Brasília: FUNASA.2005, p.446.

30. Volochko AA. saúde nos quilombos. In: Volochko A, Batista LE (org). Saúde nos quilombos. São Paulo: Instituto de Saúde; Temas em Saúde Coletiva. 9; 2009. p. 147-68.

31. Akarolo-Anthony SN, Famooto AO, Dareng EO, Olaniyan OB, Offiong R, Wheeler CM, Adebamowo CA. Age-specific prevalence of human papilloma virus infection among Nigerian women. BMC Public Health. 2014;14:656.

32. Watson-Jones D, Baisley K, Brown J, Kavishe B, Andreasen A, Changalucha J, et al. High prevalence and incidence of human papillomavirus in a cohort of healthy young African female subjects. Sex Transm Infect. 2013;89:358-65.

33. Cervantes J, Lema C, Hurtado L, Andrade R, Quiroga G, Garcia G, et al. Prevalence of human papillomavirus infection in rural villages of the Bolivian Amazon. Rev Inst Med Trop S Paulo. 2003:45(3):131-5.

34. Pinto DS, Fuzii HT, Quaresma JAS. Prevalência de infecção genital pelo HPV em populações urbana e rural da Amazônia Oriental Brasileira. Cad Saúde Pública. 2011;27(4):769-77.

35. Casalegno JS, Benchaib M, Le Bail Carval K, Piaton E, Mathevet P, Mekki Y. Human papillomavirus genotype distribution among French women with and without cervical abnormalities. Int J Gynaecol Obstet. 2011;114(2):116-9.

36. Xue H, Lin X, Li T, Yan X, Guo K, Zhang Y. Prevalence and genotype distribution of human papillomavirus infection in asymptomatic women in Liaoning province, China. J Med Virol. 2015;87(7):1248-53.

37. Goldman B, Rebolj M, Rygaard C, Preisler S, Ejegod DM, Lynge E, Bonde J. Patterns of cervical coinfection with multiple human papilloma virus types in a screening population in Denmark. Vaccine. 2013;31(12):1604-9.

38. Foliaki S, Brewer N, Pearce N, Snijders PJ, Meijer CJ, Waqatakirewa L, Clifford GM, Franceschi S. Prevalence of HPV infection and other risk factors in a Fijian population. Infect Agent Cancer. 2014;9:14

39. Marks MA, Gupta S, Liaw KL, Tadesse A, Kim E, Phongnarisorn C, et al. Prevalence and correlates of HPV among women attending family-planning clinics in Thailand. BMC Infect Dis. 2015;15(1):159.

40. Jing $L$, Zhong $X$, Huang W, Liu Y, Wang M, Miao Z, et al. HPV genotypes and associated cervical cytological abnormalities in women from the Pearl River Delta region of Guangdong province, China: a cross-sectional study. BMC Infect Dis. 2014;14:388.

41. Keita N, Clifford GM, Koulibaly M, Douno K, Kabba I, Haba M. HPV infection in women with and without cervical cancer in Conakry, Guinea. Br J Cancer. 2009. 7;101(1):202-8.

\section{Submit your next manuscript to BioMed Central and we will help you at every step:}

- We accept pre-submission inquiries

- Our selector tool helps you to find the most relevant journal

- We provide round the clock customer support

- Convenient online submission

- Thorough peer review

- Inclusion in PubMed and all major indexing services

- Maximum visibility for your research

Submit your manuscript at www.biomedcentral.com/submit 